\title{
Two free isoforms of ovine glycoprotein hormone $\alpha$-subunit strongly differ in their ability to stimulate prolactin release from foetal pituitaries
}

\author{
V Chabot, T Magallon, C Taragnat and Y Combarnous \\ Station de Physiologie de la Reproduction des Mammifères Domestiques, URA-CNRS 1291, Institut National de la Recherche Agronomique, 37380 , \\ Nouzilly, France \\ (Requests for offprints should be addressed to Y Combarnous, Station PRMD, INRA, 37380 Nouzilly, France)
}

\begin{abstract}
$\alpha$-Subunit dissociated from glycoprotein hormones has been previously shown to stimulate rat pituitary lactotroph differentiation and proliferation. However, whether the free form of the $\alpha$-subunit (free $\alpha$ ) can also play such a role is not known. To test whether free $\alpha$ may act on prolactin $(\mathrm{PRL})$ release from ovine foetal pituitaries, this molecule was purified and two major isoforms, $\alpha \mathrm{A}$ and $\alpha \mathrm{B}$ were isolated. Free $\alpha \mathrm{A}$ was found to be more acidic and more hydrophobic than both free $\alpha \mathrm{B}$ and ovine LH $\alpha$-subunit $(\mathrm{oLH} \alpha)$. Free $\alpha \mathrm{A}$ and oLH $\alpha$ exhibited a molecular mass of $14 \mathrm{kDa}$ as determined by mass spectrometry, whereas free $\alpha \mathrm{B}$ displayed a molecular mass of only $13.5 \mathrm{kDa}$ because of its truncated $\mathrm{N}$-terminus. All three $\alpha$ molecules bear mature-type N-linked saccharide chains including $\mathrm{N}-$ acetyl galactosamine residues but none of them contains O-linked oligosaccharide.

The free $\alpha \mathrm{A}$ isoform, more than the oLH $\alpha$, was able to stimulate PRL release from ovine foetal pituitary explants
\end{abstract}

in culture, whereas the free $\alpha \mathrm{B}$ isoform displayed no activity. Moreover, the free $\alpha \mathrm{A}$ and $\alpha \mathrm{B}$ isoforms were able to recombine with the ovine LH $\beta$-subunit (oLH $\beta$ ). The free $\alpha \mathrm{B} / \mathrm{oLH} \beta$, and the oLH $\alpha / \mathrm{oLH} \beta$ dimer were 4-fold more active than the free $\alpha \mathrm{A} / \mathrm{oLH} \beta$ dimer in a specific $\mathrm{LH}$ radioreceptor assay and in the stimulation of testosterone release from rat Leydig cells.

The present study demonstrates that the two free $\alpha$ isoforms of ovine glycoprotein hormones exhibit distinct efficiencies in stimulating PRL release from ovine foetal pituitaries. Moreover, despite their identical ability to recombine with the oLH $\beta$, the free $\alpha$ isoform, which is the most efficient on PRL release, is the least efficient in conferring LH activity on the $\alpha / \beta$ dimer.

Journal of Endocrinology (2000) 164, 287-297

\section{Introduction}

The glycoprotein hormones, luteinising hormone (LH), follicle-stimulating hormone (FSH), thyroid-stimulating hormone (TSH) and chorionic gonadotrophin (CG) consist of two non-covalently linked subunits named $\alpha$ and $\beta$ (Pierce \& Parsons 1981). The combination between the common $\alpha$-subunit and the hormone specific $\beta$-subunit confers its biological activity to the $\alpha / \beta$ dimer (Combarnous 1992). In addition to the combined forms, a large amount of a free form of the $\alpha$-subunit (free $\alpha$ ) has been found in the adult pituitary of different species (Hagen \& McNeilly 1975, Prentice \& Ryan 1975, Bloomfield et al. 1978, Hoshina \& Boime 1982, Bousfield \& Ward 1984), as well as in human placenta (Vaitukaitis 1974) and extraembryonic coelomic fluid (Iles et al. 1992).

Little is known about the specific biological function of the free $\alpha$ and more particularly concerning the relationships between structural differences and biological activity.
The effect of free $\alpha$ has only been studied in human placenta where it is capable of stimulating the secretion of prolactin (PRL) from human decidual cells in primary cultures with the same efficiency as the human CG (hCG) $\alpha$-subunit (Blithe et al. 1991). In women, during the menstrual cycle, $\alpha$-subunit acts synergistically with progesterone to induce decidualisation of human endometrial stromal cells (Moy et al. 1996). Moreover, some studies have reported that dissociated LH $\alpha$-subunit from glycoprotein hormones stimulates lactotroph differentiation and proliferation in rat pituitary, either in the foetus or during the postnatal period (Bégeot et al. 1984, Van Bael \& Denef 1996). Whether free $\alpha$, which may exhibit structural differences compared with dissociated LH $\alpha$-subunit, has a similar effect is not known.

Indeed, free $\alpha$ and $\alpha$-subunit display different biochemical features mainly resulting from their distinct carbohydrate compositions (Kourides et al. 1980a, Parsons et al. 1983, Blithe \& Nisula 1985, Kawano et al. 1988, 
Blithe 1990a, Bousfield \& Ward 1992). Hence, human placental free $\alpha$ possesses two more complex N-linked oligosaccharides and occasionally an additional O-linked oligosaccharide (Cole et al. 1984, Corless et al. 1987, Peters et al. 1989, Blithe 1990a). However, differences in the glycosylation between placental free $\alpha$ and dissociated hCG $\alpha$-subunit do not seem to be important for their ability to stimulate PRL. Bovine and equine pituitary free $\alpha$ bear an additional O-linked oligosaccharide on threonine 43 (Parsons et al. 1983, Ward et al. 1989). In all cases, these differences in carbohydrate structures prevent the free $\alpha$ molecule from combining in vitro with the $\beta$-subunit (Parsons \& Pierce 1984, Saccuzzo-Beebe et al. 1989, Blithe 1990b, Blithe \& Iles 1995). To our knowledge, no data are available concerning the structure and/or the function of ovine pituitary free $\alpha$.

The aim of the present work was first to determine whether ovine free $\alpha$ molecules exhibit a specific function in ovine foetal pituitary compared with the ovine LH $\alpha$-subunit (oLH $\alpha$ ). The second objective was to establish whether free $\alpha$ molecules and oLH $\alpha$ display different structural features that may be correlated to their respective functions

\section{Materials and Methods}

\section{Purification of ovine free a isoforms}

One kilogram of frozen pituitaries from adult sheep was finely ground in cold acetone $\left(-20^{\circ} \mathrm{C}\right)$ using an Ultra Turax mixer and the resulting material was filtered through filter paper. Acetone from the retentate was evaporated for 24-36 h under air circulation. The dry 'cake' was then reduced to fine powder using a coffee grinder. The yield was $182 \mathrm{~g}$ acetone powder per $\mathrm{kg}$ fresh pituitaries. The acetone powder was vigorously dispersed in 1 litre $0.15 \mathrm{M}$ ammonium sulphate $\mathrm{pH} 4.4$ at $4{ }^{\circ} \mathrm{C}$, using an Ultra Turax mixer for $10-15 \mathrm{~s}$ and was then agitated for $90 \mathrm{~min}$ in a cold-room. After centrifugation $\left(3000 \mathrm{~g}, 35 \mathrm{~min}, 4{ }^{\circ} \mathrm{C}\right)$ the supernatant $(\mathrm{S} 1)$ was recovered and the pellet was re-extracted in 1 litre $0.15 \mathrm{M}$ ammonium sulphate $\mathrm{pH} 5.7$ at $4{ }^{\circ} \mathrm{C}$ for $1 \mathrm{~h}$. The supernatant recovered after centrifugation as above $\left(\mathrm{S}^{\prime} 1\right)$ was added to S1. Metaphosphoric acid was then added to the supernatant $\mathrm{S} 1+\mathrm{S}^{\prime} 1$ at $4{ }^{\circ} \mathrm{C}$ under efficient agitation until $\mathrm{pH} 3 \cdot 2$ was reached. After immediate centrifugation, the supernatant was recovered (S2; 1.71$)$ and solid ammonium sulphate was added up to $1 \cdot 2 \mathrm{M}$ final concentration. After $1 \mathrm{~h}$ at $4{ }^{\circ} \mathrm{C}$ and centrifugation, the resulting pellet was dialysed and lyophilised (precipitate at $1.2 \mathrm{M}: 1.626 \mathrm{~g}$ ) whereas the supernatant $(1.8 \mathrm{l})$ had ammonium sulphate added up to $2 \cdot 0 \mathrm{M}$ final concentration. After $1 \mathrm{~h}$ at $4{ }^{\circ} \mathrm{C}$ and centrifugation, the resulting pellet was dialysed and lyophilised (precipitate at $2.0 \mathrm{M}: 1.471 \mathrm{~g}$ ) whereas the supernatant $(1.95 \mathrm{l})$ was brought to $3.6 \mathrm{M}$ ammonium sulphate. After overnight incubation at $4{ }^{\circ} \mathrm{C}$, the pellet (precipitate at $3.6 \mathrm{M}$ ) was recovered by centrifugation. The fractions containing free $\alpha$ isoforms were determined at each step of purification by an enzyme-linked immunosorbent assay (ELISA) specific for the oLH $\alpha$. Free $\alpha$ was found only in the $3.6 \mathrm{M}$ precipitate, which was dissolved in $220 \mathrm{ml} 1 \mathrm{M}$ ammonium sulphate and loaded onto a phenyl-Sepharose column (volume $200 \mathrm{ml}$; Pharmacia, Orsay, France) equilibrated with $1 \mathrm{M}$ ammonium sulphate in $50 \mathrm{mM}$ ammonium bicarbonate. After elution of the unretained fraction, the column was eluted stepwise with 0.5 and $0.2 \mathrm{M}$ ammonium sulphate in $50 \mathrm{mM}$ ammonium bicarbonate, then by $50 \mathrm{mM}$ ammonium bicarbonate alone and finally with $50 \%$ ethylene glycol in $50 \mathrm{mM}$ ammonium bicarbonate. Free $\alpha$ was mainly found in the fraction eluted with $0.5 \mathrm{M}$ ammonium sulphate (also containing $\mathrm{FSH}$ ) and in the fraction eluted with $0 \cdot 2 \mathrm{M}$ ammonium sulphate (containing very low amounts of FSH and $\mathrm{LH}$ ). Free $\alpha$ from these fractions was isolated by low pressure chromatography on a Sephacryl S-200 column $(2 \times 85 \mathrm{~cm}$, Pharmacia) and then by a final size-exclusion HPLC (SE-HPLC) on a Waters (St Quentin en Yvelines, France) chromatograph (625 LC system) using two Superdex 75 high resolution columns (Pharmacia) in tandem equilibrated with $100 \mathrm{mM}$ ammonium bicarbonate, at a flow rate of $0.4 \mathrm{ml} / \mathrm{min}$.

\section{Purification of dissociated oLHa and $\beta$ subunits}

Ovine LH CY 1083 purified in our laboratory $(3.5 \times \mathrm{NIH}$ LH S1) was dissociated into its constituent subunits by incubation in $0.1 \mathrm{M}$ sodium phosphate/citrate buffer $\mathrm{pH}$ $4 \cdot 0$, for $5 \mathrm{~min}$ at $55^{\circ} \mathrm{C}$ at a final concentration of $1 \mathrm{mg} / \mathrm{ml}$. The ovine LH $\beta$-subunit $(\mathrm{oLH} \beta)$ was precipitated by $3 \mathrm{M}$ $\mathrm{NaCl}$ final concentration for $1 \mathrm{~h}$ at $4{ }^{\circ} \mathrm{C}$ (Sairam \& $\mathrm{Li}$ 1974). After centrifugation $(3000 \mathrm{~g}, 20 \mathrm{~min})$, the supernatant was recovered and the pellet was re-precipitated by $3 \mathrm{M} \mathrm{NaCl}$, for $1 \mathrm{~h}$ at $4{ }^{\circ} \mathrm{C}$. The supernatant recovered after centrifugation as above was added to the first supernatant, dialysed against water and the oLH $\alpha$ was recovered after lyophilisation. The pellet (containing oLH $\beta$ ) was re-suspended in $0 \cdot 1 \mathrm{M}$ sodium phosphate/ citrate buffer $\mathrm{pH} 4 \cdot 0$, dialysed and lyophilised. To remove eventual oLH contaminant, oLH $\alpha$ and oLH $\beta$ were purified by SE-HPLC (as above). LH contamination, estimated by an in vitro bioassay specific for LH activity (see below), was less than $1 \cdot 5 \%$ and $1 \%$ for oLH $\alpha$ and oLH $\beta$ respectively.

\section{oLHa ELISA}

The fractions containing free $\alpha$ were determined at each step of purification by a competitive ELISA specific for the dissociated oLHa. Microtitration plates (96 wells; CML, Angers, France) were coated with purified oLH $\alpha$ (10 ng/ $100 \mu \mathrm{l}$ in $0 \cdot 1 \mathrm{M}$ carbonate buffer, $\mathrm{pH} 9 \cdot 6)$ for $1 \mathrm{~h}$ at $37^{\circ} \mathrm{C}$ and then overnight at $4{ }^{\circ} \mathrm{C}$. After washing and saturation 
with $0 \cdot 2 \%$ BSA in $0 \cdot 1 \mathrm{M}$ PBS $/ 0 \cdot 1 \%$ Tween 20 , an antibody against dissociated porcine $\mathrm{LH} \alpha(1 / 10$ 000) was added to the wells together with the fraction at varying concentrations, for $1 \mathrm{~h}$ at $37^{\circ} \mathrm{C}$. Antibody excess was then washed off with PBS/Tween and the bound antibody fraction was detected with horseradish peroxidase-labelled goat anti-rabbit $\operatorname{IgG}(1 / 1000)$ (Sanofi/Pasteur Diagnostics, Marnes-la-Coquette, France). After $1 \mathrm{~h}$ at $37^{\circ} \mathrm{C}$ and washing, peroxidase activity was measured with hydrogen peroxide and tetramethylbenzidine (Sigma, St Quentin Fallavier, France) as substrates (Bos et al. 1981). After stopping the reaction with $1 \mathrm{M} \mathrm{H}_{2} \mathrm{SO}_{4}$, the signal was measured with an ELISA reader (Multiskan Plus; Labsystemsx, Helsinki, Finland) at $450 \mathrm{~nm}$. The minimum detectable concentration of oLH $\alpha$ was $10 \mathrm{ng} /$ $\mathrm{ml}$. Mean intra- and inter-assay coefficients of variation (CV) were less than 8.3 and $7 \cdot 8 \%$ respectively. Crossreaction with highly purified oLH CY1085 $(3.45 \times \mathrm{NIH}$ LH S1), oFSH CY1767 $(32 \times$ NIH FSH S1 $)$ and oTSH (NIADDK oTSH-12) was $3 \cdot 5,0 \cdot 2$ and $8 \cdot 8 \%$ respectively.

\section{SDS-polyacrylamide gel electrophoresis (PAGE)}

SDS-PAGE under reducing conditions was performed in $15 \%$ polyacrylamide gel (acrylamide/bis 29:1; Bio-Rad, Richmond, CA, USA), pH 8.8 according to the method of Laemmli (1970). The samples were dissolved in a solution containing $4 \%$ SDS and 10\% $\beta$-mercaptoethanol and heated to $100^{\circ} \mathrm{C}$ for $5 \mathrm{~min}$. Proteins were stained with Coomassie blue.

\section{Electrospray ionisation mass spectrometry (ES/MS)}

ES/MS was used to compare the masses of free $\alpha$ and oLH $\alpha$. Lyophilised purified free $\alpha$ was dissolved in water/ acetonitrile $(50 / 50, \mathrm{v} / \mathrm{v})$ containing $0 \cdot 2 \%$ formic acid. Sample volumes of $3 \mu \mathrm{l}(0 \cdot 3 \mu \mathrm{g}$ free $\alpha)$ were introduced by flow injection into the electrospray source at a flow rate of $3 \mu \mathrm{l} / \mathrm{min}$. The calibration of the mass/charge scale was carried out by prior analysis of erythropoietin.

\section{Polyacrylamide gel electrophoresis (PAGE)}

The charge heterogeneity of the purified material was estimated by PAGE on 7\% polyacrylamide gel, $\mathrm{pH} 9 \cdot 5$ according to the method of Liao et al. (1969) with minor modifications.

\section{Reverse-phase HPLC (RP-HPLC)}

Differences in hydrophobic interactions were determined using a reverse-phase C18 column $(5 \mu$ Deltapack; Waters) with a linear $80 \mathrm{~min}$ gradient from 0 to $90 \%$ acetonitrile in $0 \cdot 1 \%$ trifluoroacetic acid (TFA) at a flow rate of $0.5 \mathrm{ml} / \mathrm{min}$, at $40{ }^{\circ} \mathrm{C}$.

\section{$\mathrm{N}$-terminal amino acid sequence}

$\mathrm{N}$-terminal amino acid sequence was determined with a Beckman (Villepinte, France) automated Edman protein sequencer after SDS-PAGE in 15\% polyacrylamide gel with $\beta$-mercaptoethanol and transfer to a polyvinylidene difluoride (PVDF) membrane.

\section{Carbohydrate analysis}

After methanolysis of oligosaccharides of free $\alpha$ isoforms with $0.5 \mathrm{M}$ methanol/ $\mathrm{HCl}$ for $24 \mathrm{~h}$ at $80{ }^{\circ} \mathrm{C}$ and peracetylation, neutral and amino sugars were analysed on a gas chromatograph (Delsi, DI 700; Rueil Malmaison, France) equipped with a flame ionisation detector.

\section{Neuraminidase treatment}

To study the role of sialic acids in charge heterogeneity, the purified free $\alpha$ and oLH $\alpha(20 \mu \mathrm{g} / 10 \mu \mathrm{l})$ were treated with $5 \mathrm{mU} / \mathrm{mg}$ protein of neuraminidase from Clostridium perfringens (Type X; Sigma) in $20 \mathrm{mM}$ sodium phosphate buffer, $\mathrm{pH} 6.0$, for $4 \mathrm{~h}$ at $37^{\circ} \mathrm{C}$. Fetuin (Sigma) was used as a control of desialylation. Samples were analysed by PAGE in $7 \%$ polyacrylamide gel.

\section{Peptide-N-glycosidase F (PNGase F) and O-glycosidase treatments}

For characterisation of the free $\alpha$ isoforms and oLH $\alpha$ oligosaccharides, the three $\alpha$ molecules were incubated with PNGase F (Boehringer Mannheim, Meylan, France) following neuraminidase and $\mathrm{O}$-glycosidase (endo- $\alpha-\mathrm{N}-$ acetylgalactosaminidase; France Biochem, Meudon, France) treatments. The proteins were dissolved in $0 \cdot 1 \mathrm{M}$ sodium phosphate, $1 \mathrm{mM}$ EDTA, $10 \mathrm{mM}$ dithiothreitol, $0.5 \%$ SDS, pH 6.0 at a final concentration of $5 \mu \mathrm{g} / \mu \mathrm{l}$ and boiled for 3 min. After cooling, Nonidet P-40 and phenylmethylsulphonylfluoride were added at final concentrations of $0.7 \%$ and $1 \mathrm{mM}$ respectively. The denatured $\alpha$ molecules were then digested with $50 \mathrm{mU}$ PNGase F/ $\mu \mathrm{g}$ protein at $37{ }^{\circ} \mathrm{C}$ for $24 \mathrm{~h}$ at a concentration of $2 \mu \mathrm{g} /$ $\mu \mathrm{l}$. Samples were analysed by SDS-PAGE in $15 \%$ polyacrylamide gel under reducing conditions as above. For O-glycosidase treatment, half of the PNGase Ftreated samples were first incubated with $5 \mathrm{mU}$ neuraminidase/mg protein for $4 \mathrm{~h}$ at $37^{\circ} \mathrm{C}$. Then, the $\mathrm{pH}$ was adjusted to $4 \cdot 5$ with $0 \cdot 1 \mathrm{M}$ phosphate/citrate buffer $\mathrm{pH} 3.5$ and the samples were incubated with $0.05 \mathrm{mU}$ O-glycosidase/ $\mu$ g protein at $37^{\circ} \mathrm{C}$ for $24 \mathrm{~h}$ and analysed by SDS-PAGE.

\section{Recombination with oLH $\beta$}

The reactions were performed by incubating equimolar amounts of either oLH $\alpha$, free $\alpha \mathrm{A}$ or $\alpha \mathrm{B}$ with oLH $\beta$ in 
$0 \cdot 1 \mathrm{M}$ ammonium bicarbonate, for $24 \mathrm{~h}$ at $37^{\circ} \mathrm{C}$, at a final concentration of $3.3 \mathrm{mg} / \mathrm{ml}$. The percentage of reconstituted dimers was estimated by SE-HPLC on two Superdex 75HR columns in tandem by measuring the ratio between the heterodimer peak area and the total peak area (PDA software; Waters).

\section{$L H$ radioligand assay}

Receptor binding activity of reconstituted dimers was determined on rat testicular membranes as previously described (Guillou et al. 1985). Rat testicular membranes were incubated overnight with a fixed amount of ovine ${ }^{125}$ I-LH (30 000 c.p.m.) and increasing amounts of reconstituted dimers at room temperature. After incubation, bound and free hormone were separated by centrifugation $\left(2000 \mathrm{~g}, 45 \mathrm{~min}\right.$ at $\left.4{ }^{\circ} \mathrm{C}\right)$, the supernatant was discarded and the radioactivity of the pellet was counted in a gamma counter (Multidetector RIA system 95424; Packard, Rungis, France).

\section{In vitro bioassay for LH activity}

Reconstituted dimers bioactivity was assayed in vitro by determining testosterone release from cultured rat Leydig cells. Rat Leydig cells were isolated as previously described (Guillou et al. 1985) and incubated for $4 \mathrm{~h}$ at $34{ }^{\circ} \mathrm{C}$ with increasing concentrations of reconstituted dimers. Testosterone concentration in the culture medium was estimated by a specific RIA (Guillou et al. 1985).

\section{Culture of ovine foetal pituitary explants}

Sheep foetuses were obtained by Caesarean section at 50 days of gestation from crossbred Ile de France $x$ Romanov ewes. Pituitaries were removed after decapitation from female foetuses, weighed and collected in Dulbecco's modified Eagle's medium (DMEM) (Sigma) containing transferrin $(10 \mu \mathrm{g} / \mathrm{ml})$, ascorbic acid $(17.6 \mu \mathrm{g} /$ $\mathrm{ml}$ ) and antibiotics. Each pituitary was cut in half in the sagittal plane under a microscope and the posterior pituitary was removed. Cultures of explants were established according to the method described by Watanabe et al. (1973) with minor modifications. Briefly, each half pituitary was placed on a round piece of cellulose acetate (13 mm diameter) (Millipore, St Quentin en Yvelines, France) on stainless mesh platforms in a culture dish. The culture dishes were placed at $37^{\circ} \mathrm{C}$ in a $5 \% \mathrm{CO}_{2}$ atmosphere. Explants were maintained in culture over 8 days in DMEM containing $0 \cdot 2 \%$ human serum albumin alone or with free $\alpha \mathrm{A}$, free $\alpha \mathrm{B}$ or oLH $\alpha$ at a concentration of $10^{-7} \mathrm{M}$. The oLH $\beta$ and oLH $\left(10^{-7} \mathrm{M}\right)$ were used as negative controls. The medium was changed every day and assayed for PRL by a specific enzyme immunoassay. Each condition was run in duplicate.
Competitive enzyme immunoassay for PRL

PRL released into the culture medium was assayed using a specific competitive enzyme immunoassay. Microtitration plates (96 wells, CML) were coated with $100 \mathrm{ng} /$ $100 \mu \mathrm{loPRL}$ CY $1101 \mathrm{III}$ purified in our laboratory (22 IU/mg). The anti-bovine PRL serum (Dubois 1971) at $1 / 160000$ initial dilution was preincubated with increasing concentrations of standard oPRL (oPRL CY 1101 III) or the samples for $2 \mathrm{~h}$ at $37^{\circ} \mathrm{C}$. One hundred microlitres of the mixture were added to the wells for $1 \mathrm{~h}$ at $37^{\circ} \mathrm{C}$ and, thereafter, the procedure was similar to that used for oLH $\alpha$ ELISA (see above).

The minimum detectable concentration of oPRL was $3 \mathrm{ng} / \mathrm{ml}$. Mean intra- and inter-assay CVs were less than 8.0 and $11.5 \%$ respectively. Cross-reaction with ovine growth hormone (NIADDK oGH-I-4) was 0.2\%.

\section{Statistical analysis}

Values are expressed as the mean \pm S.E.M. of three to five independent experiments. After $\log _{10}$ transformation of the data, the effect of the treatment throughout the culture was determined by ANOVA with repeated measures followed by two-factor ANOVA for individual comparisons. Experiment effect was taken into account and no interaction between treatment and experiments was observed.

\section{Results}

Purification of the free $\alpha A$ and $a B$ isoforms

Ovine free $\alpha$ molecules were detected by a specific immunoassay in fractions II and III of the hydrophobic interaction chromatography, suggesting that free $\alpha$ molecules with different hydrophobicity (III > II) were separated.

After the final step of SE-HPLC, $9 \cdot 2 \mathrm{mg}$ free $\alpha \mathrm{A}$ (from fraction III) and $16 \mathrm{mg}$ free $\alpha \mathrm{B}$ (from fraction II) isoforms were obtained from $1 \mathrm{~kg}$ pituitaries.

\section{Structural characterisation of the free $\alpha A$ and $\alpha B$ isoforms}

A single band was revealed in SDS-PAGE (data not shown) as well as a single peak in SE-HPLC (Fig. 1a and b ) for both free $\alpha \mathrm{A}$ and $\alpha \mathrm{B}$ suggesting that they consisted of highly purified free $\alpha$ isoforms.

Size In both SE-HPLC (Fig. 1a) and SDS-PAGE (data not shown), free $\alpha A$ and oLH $\alpha$ displayed similar size whereas free $\alpha \mathrm{B}$ exhibited a slightly smaller apparent size (Fig. 1b). This result was confirmed by ES/MS analysis (Fig. 2) since the oLH $\alpha$, free $\alpha \mathrm{A}$ and free $\alpha \mathrm{B}$ molecular masses were respectively in the range of $13200-$ $14500 \mathrm{Da}$ (maximum 13 937), 13 600-14 $500 \mathrm{Da}$ (maximum 14 019) and 13 017-14 $147 \mathrm{Da}$ (maximum 13 514). 


\section{Free $\alpha \mathbf{A}$}
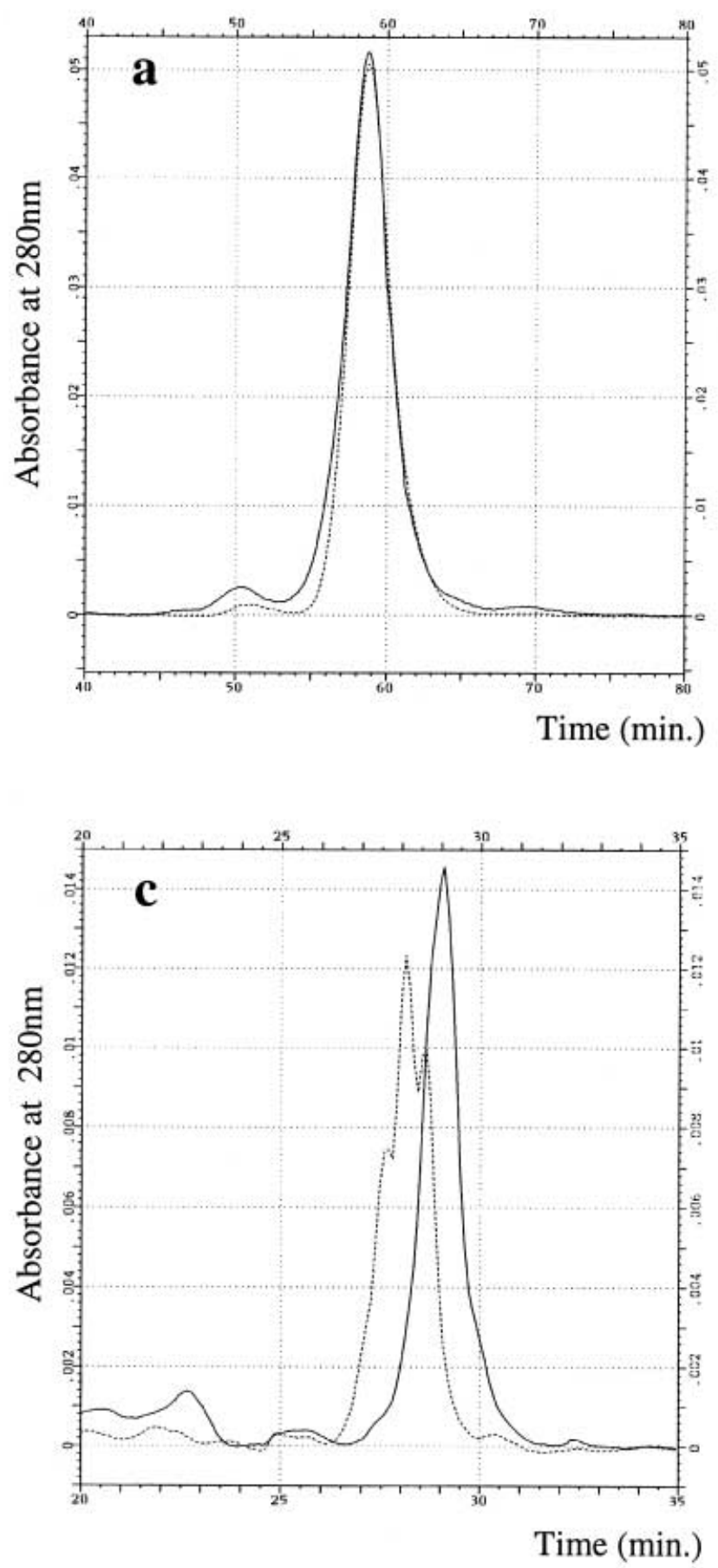

Free $\alpha \mathbf{B}$
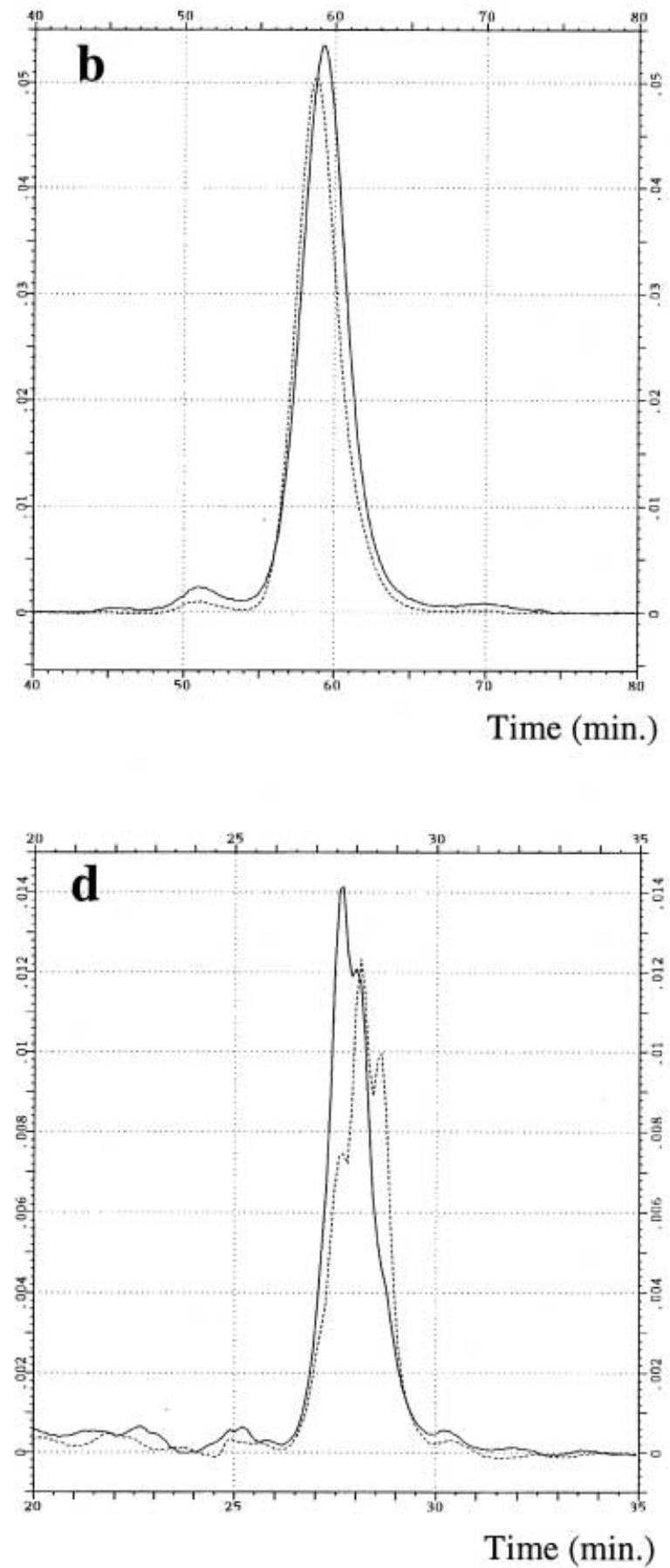

Figure $1(\mathrm{a}, \mathrm{b})$ SE-HPLC of the two free $\alpha$ isoforms (solid line) and oLH $\alpha$ (broken line) on two Superdex 75 HR columns in series. The elution buffer was $100 \mathrm{mM}$ ammonium bicarbonate at a flow rate of $0.4 \mathrm{ml} / \mathrm{min}$. (c, d) RP-HPLC of the two ovine free $\alpha$ isoforms (solid line) and oLH $\alpha$ (broken line) on a C18 column using a linear gradient from 0 to $90 \%$ acetonitrile in $0 \cdot 1 \%$ TFA, with a flow rate of $0.5 \mathrm{ml} / \mathrm{min}$ at $40{ }^{\circ} \mathrm{C}$. 


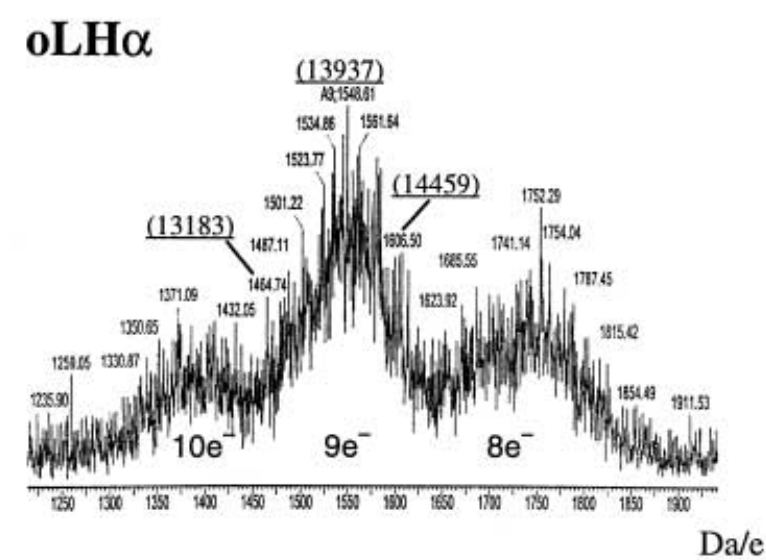

\section{Free $\alpha \mathbf{A}$}

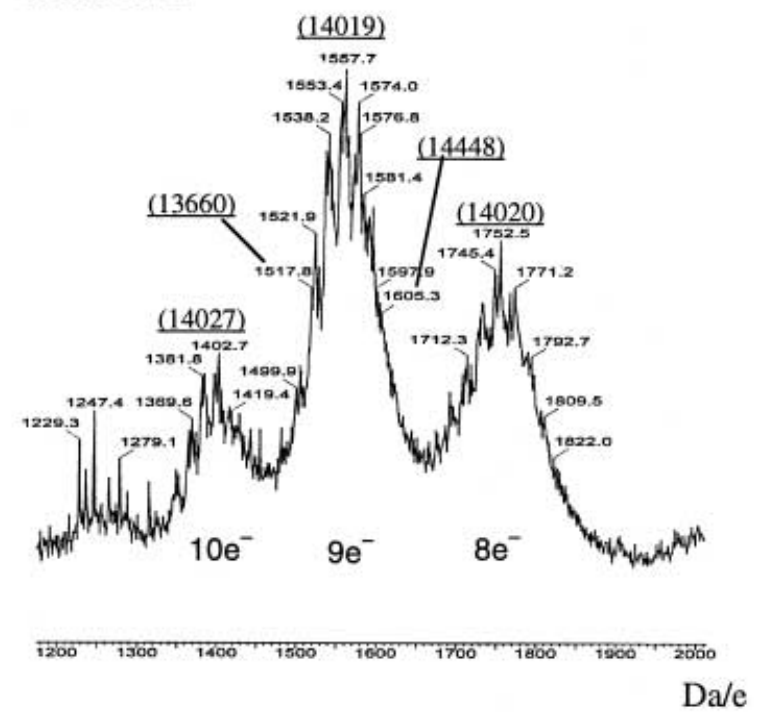

\section{Free $\alpha \mathbf{B}$}
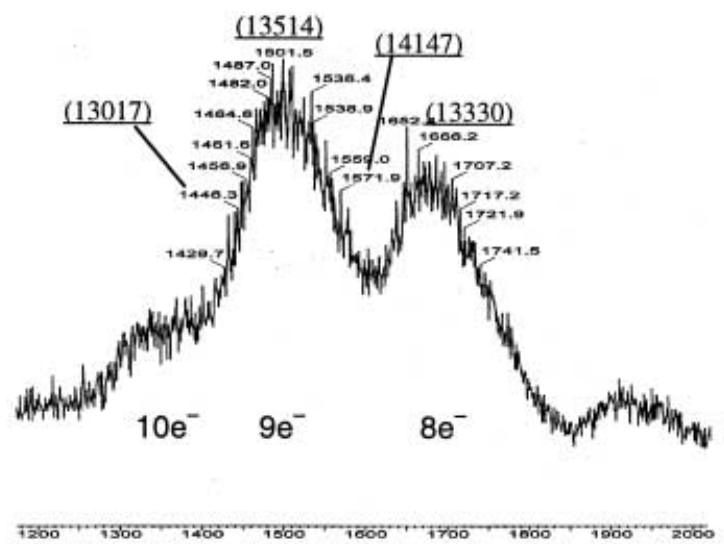

$\mathrm{Da} / \mathrm{e}$
$\mathrm{oLH} \alpha$

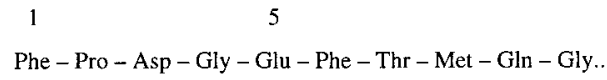

Free $\alpha A$ 15

Phe - Pro - Asp - Gly - Glu - Phe - Thr - Met - Gln - Gly ...

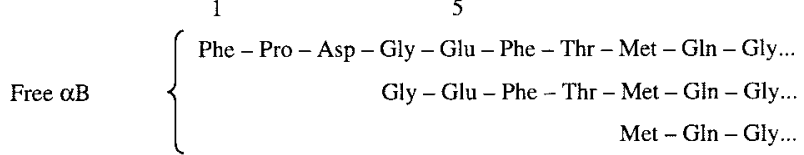

Figure $3 \mathrm{~N}$-terminal amino acid sequence of the two free $\alpha$ isoforms compared with oLH $\alpha$ determined after SDS-PAGE in 15\% polyacrylamide gel under reducing conditions and transfer to a PVDF membrane.

This represents a difference of $423 \mathrm{Da}$ between free $\alpha \mathrm{B}$ and oLH $\alpha$ on the one hand and of $505 \mathrm{Da}$ between free $\alpha \mathrm{B}$ and free $\alpha \mathrm{A}$ in the other hand.

Hydrophobicity In keeping with its behaviour in hydrophobic interaction chromatography, free $\alpha \mathrm{A}$ was more retained in RP-HPLC on a C18 column than free $\alpha \mathrm{B}$ (Fig. 1c and d). The oLH $\alpha$ was found to exhibit retention times similar to that of free $\alpha \mathrm{B}$ (Fig. 1d).

$\mathrm{N}$-terminal heterogeneity of free $\alpha$ subunits The $\mathrm{N}$-terminal amino acid sequences of free $\alpha \mathrm{A}$ and $\alpha \mathrm{B}$ were determined and compared with that of the oLH $\alpha$. As shown in Fig. 3, free $\alpha \mathrm{A}$ displayed a complete homogeneous $\mathrm{N}$-terminal sequence similar to that of oLH $\alpha$ whereas free $\alpha \mathrm{B}$ appeared to be a mixture of three polypeptides with different $\mathrm{N}$-terminal regions starting either at $\mathrm{Phe}^{1}, \mathrm{Gly}^{4}$ or $\mathrm{Met}^{8}$. The N-terminal isoforms starting at $\mathrm{Gly}^{4}$ and $\mathrm{Met}^{8}$ were the prominent forms in free $\alpha \mathrm{B}$. No contaminating sequence was detected by this technique, confirming that the preparations consisted of highly purified free $\alpha$ isoforms.

Carbohydrate analyses and charge heterogeneity Carbohydrate compositions established by gas-phase chromatography (data not shown) revealed that oligosaccharide chains in the two free $\alpha$ isoforms were of mature type with the detection of sialic acid, N-acetyl galactosamine and $\mathrm{N}$-acetyl glucosamine residues but not polymannose. Carbohydrate compositions of the two free $\alpha$ isoforms did not exhibit significant differences. Figure 4 shows that free $\alpha \mathrm{A}$ displayed more acidic charge isoforms than free $\alpha \mathrm{B}$ and oLH $\alpha$ with two major bands. Free $\alpha \mathrm{A}$

Figure $2 \mathrm{ES} / \mathrm{MS}$ spectra of oLH $\alpha$, free $\alpha \mathrm{A}$ and free $\alpha \mathrm{B}$. Da/e represents mass/charge $(\mathrm{m} / \mathrm{z})$ scale and underlined numbers show the molecular mass (Da) of the major form and the range of masses for the population of molecules. 


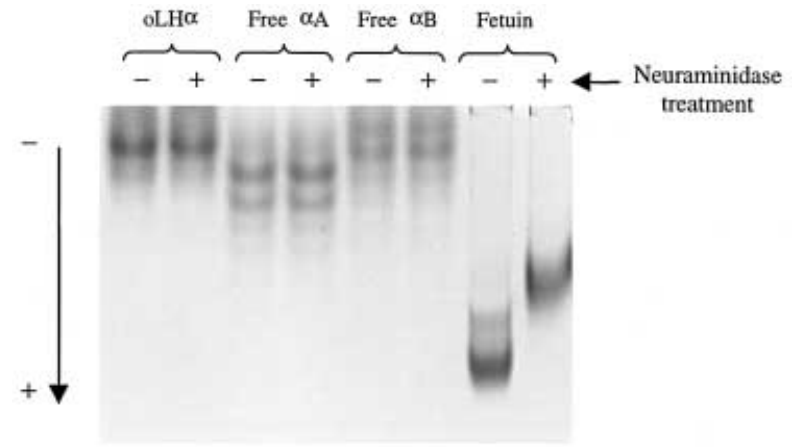

Figure 4 Native PAGE (7\% acrylamide, $\mathrm{pH}$ 9.5) of oLH $\alpha$, free $\alpha \mathrm{A}$ and free $\alpha \mathrm{B}(20 \mu \mathrm{g})$ without $(-)$ or with $(+)$ neuraminidase treatment $\left(4 \mathrm{~h}, 37^{\circ} \mathrm{C}\right)$. Fetuin was used as control of desialylation. The proteins were stained with Coomassie blue.

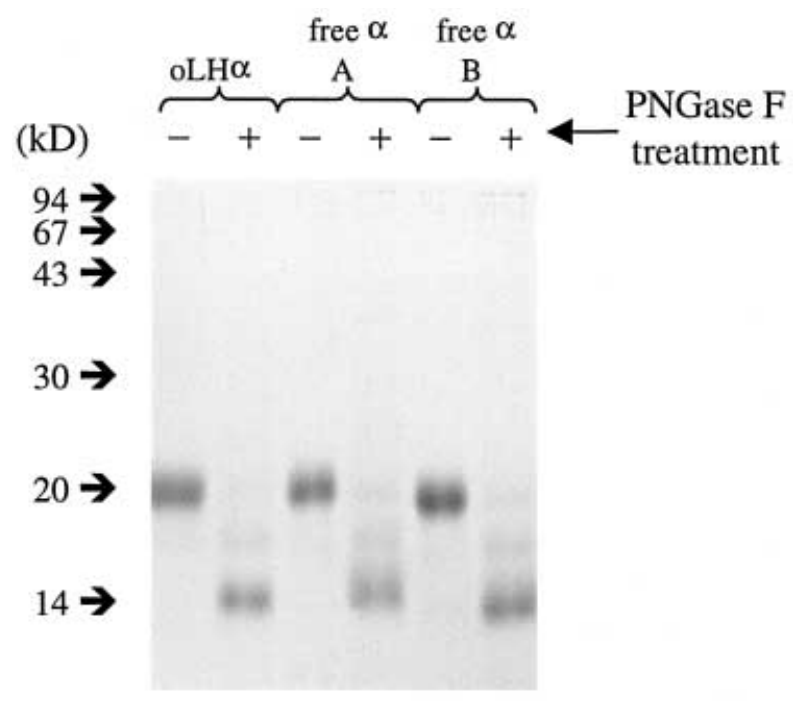

Figure 5 SDS-PAGE (15\% polyacrylamide gel) of oLH $\alpha$, free $\alpha \mathrm{A}$ and free $\alpha \mathrm{B}(3 \mu \mathrm{g})$ without $(-)$ or with $(+)$ PNGase $\mathrm{F}$ treatment $\left(24 \mathrm{~h}, 37^{\circ} \mathrm{C}\right)$. The proteins were stained with Coomassie blue. and $\alpha \mathrm{B}$ were more heterogeneous in charge than the oLH $\alpha$. There was no difference in migration between neuraminidase-treated and non-treated free $\alpha$ molecules (Fig. 4).

Deglycosylation After PNGase treatment (Fig. 5), the majority of the three $\alpha$ molecules were converted to faster migrating forms in SDS-PAGE. A major band, corresponding to an apparent molecular mass of approximately $15 \mathrm{kDa}$, probably represented $\alpha$ molecules after removal of their two N-oligosaccharide chains. The faint band with intermediate mobility on the SDS gel, corresponding to a molecular mass of approximately $18 \mathrm{kDa}$, probably represented $\alpha$ molecules after removal of only one $\mathrm{N}$ oligosaccharide chain. The difference in apparent molecular mass between the free $\alpha \mathrm{B}$ isoform and both free $\alpha \mathrm{A}$ isoform and oLH $\alpha$ persisted after PNGase F treatment.

A subsequent treatment with $\mathrm{O}$-glycosidase (data not shown) had no effect at all on the mobility of any three $\alpha$ molecules suggesting that none of them contains $\mathrm{O}$-linked oligosaccharide.

\section{Functional characterisation of free $\alpha A$ and $\alpha B$ isoforms}

Receptor binding and in vitro bioactivity of $\alpha / \beta$ heterodimers Table 1 shows the percentage of recombined dimer after $24 \mathrm{~h}$ at $37^{\circ} \mathrm{C}$ using SE-HPLC. The two free $\alpha$ isoforms were able to recombine with oLH $\beta$ with a slightly lower efficiency than that of the oLH $\alpha$. Both oLH $\alpha / \mathrm{oLH} \beta$ and free $\alpha \mathrm{B} / \mathrm{oLH} \beta$ dimers were able to bind to rat testis $\mathrm{LH}$ receptors with a similar affinity $\left(\mathrm{ED}_{50}\right.$ : $3.0 \mathrm{ng} / 100 \mu \mathrm{l})$ whereas the free $\alpha \mathrm{A} / \mathrm{oLH} \beta$ dimer was 3.5-fold less potent $\left(\mathrm{ED}_{50}: 10 \cdot 5 \mathrm{ng} / 100 \mu \mathrm{l}\right.$ ) (Fig. 6).

Recombined oLH $\alpha /$ oLH $\beta$ and free $\alpha /$ oLH $\beta$ were examined for their ability to stimulate in vitro secretion of testosterone in cultured rat testicular Leydig cells. oLH $\alpha$ / oLH $\beta$ and free $\alpha \mathrm{B} / \mathrm{oLH} \beta$ dimers stimulated testosterone release to the same extent (Fig. 7) whereas the free $\alpha \mathrm{A} / \mathrm{oLH} \beta$ dimer was 4 -fold less effective. The bioactivity/ binding ratios (Table 1) were similar for the three recombined molecules indicating that the differences in the $\alpha$

Table 1 Characteristics of relative combination, binding and stimulating activities of $\alpha / \beta$ dimers resulting from $24 \mathrm{~h}$ incubation of either oLH $\alpha$, free $\alpha \mathrm{A}$ or $\alpha \mathrm{B}$ with equimolar amounts of oLH $\beta$. The percentage of associated dimer was estimated by SE-HPLC as described in Materials and Methods. The oLH $\alpha / \mathrm{oLH} \beta$ dimer was given as reference $\left({ }^{*}\right)$. The binding and stimulating activities of free $\alpha \mathrm{A} / \mathrm{oLH} \beta$ and free $\alpha \mathrm{B} / \mathrm{oLH} \beta$ were calculated according to their $\mathrm{ED}_{50}$ compared with oLH $\alpha / \mathrm{oLH} \beta$. The experiment was repeated three times. $\mathrm{LH}$ receptor binding activity was determined by radioreceptor assay using ${ }^{125} \mathrm{I}$-labelled $\mathrm{oLH}$ and rat testicular membranes. In vitro LH bioactivity was determined by stimulation of testosterone release from cultured rat testicular Leydig cells

\begin{tabular}{|c|c|c|c|c|}
\hline & Associated dimer & Binding (B) & Stimulation (S) & S/B \\
\hline $\mathrm{oLH} \alpha / \mathrm{oLH} \beta$ & $100^{*}$ & $100^{*}$ & $100^{*}$ & 1 \\
\hline Free $\alpha \mathrm{A} / \mathrm{oLH} \beta$ & 87 & 29 & 24 & $0 \cdot 83$ \\
\hline Free $\alpha \mathrm{B} / \mathrm{oLH} \beta$ & 87 & 92 & 120 & $1 \cdot 3$ \\
\hline
\end{tabular}




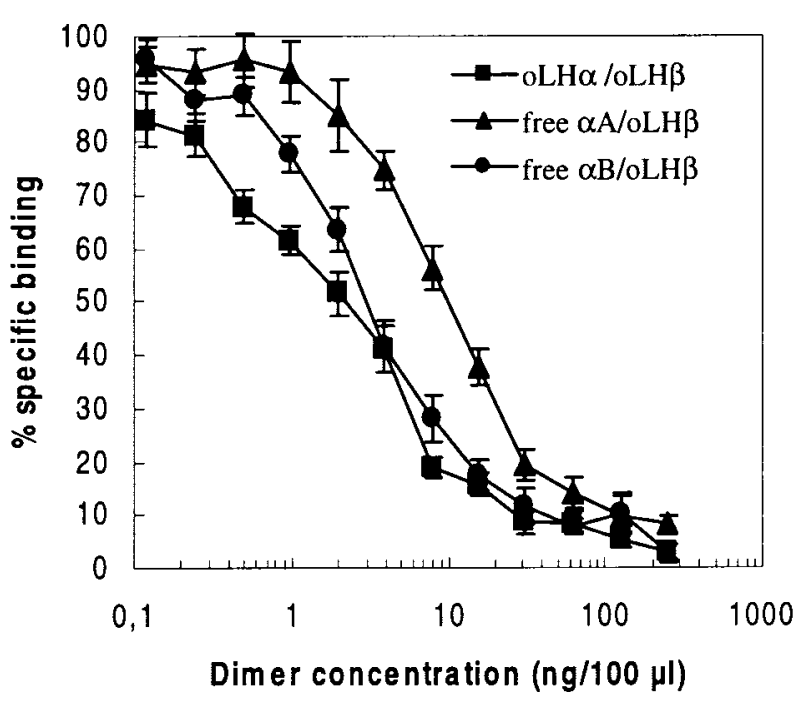

Figure 6 Binding activity of oLH $\alpha / \mathrm{oLH} \beta$ and free $\alpha / \mathrm{oLH} \beta$ dimers to membranes isolated from rat testis. The membranes were incubated overnight at room temperature with ${ }^{125}$ I-labelled oLH in the absence or presence of varying concentrations of either unlabelled recombined oLH $\alpha / \mathrm{oLH} \beta$ or free $\alpha / \mathrm{oLH} \beta$ dimers. Values are mean \pm S.E.M. of three independent experiments.

moieties do not interfere with signal transduction of the heterodimers upon binding.

Effects of free $\alpha A, \alpha B$ isoforms and oLH $\alpha$ on PRL release in foetal pituitary explants Figure 8 a shows that continuous treatment of ovine female foetal pituitary explants with free $\alpha \mathrm{A}$ for 8 days leads to stimulation of PRL release $(P<0 \cdot 001$ compared with the control). When

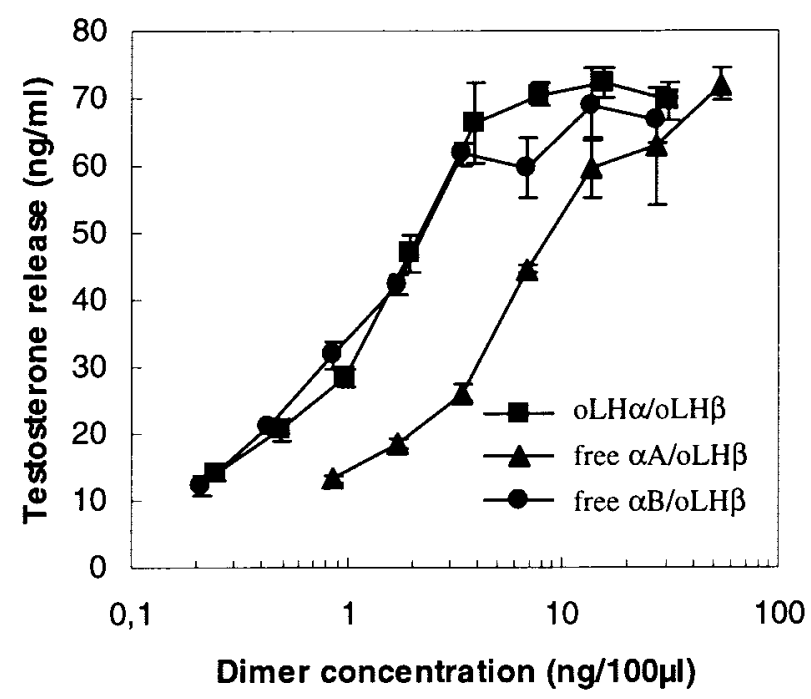

Figure 7 In vitro bioactivity of oLH $\alpha / \mathrm{oLH} \beta$ and free $\alpha / \mathrm{oLH} \beta$ dimers in rat Leydig cell assay $\left(4 \mathrm{~h}, 34^{\circ} \mathrm{C}\right)$. Testosterone released into the culture medium was measured by a specific RIA. Each point is the mean \pm S.E.M. of one representative experiment. the pituitary explants were chronically treated with free $\alpha \mathrm{B}, \mathrm{PRL}$ release was not different from the control (Fig. $8 \mathrm{~b})$. A slight stimulatory effect of the oLH $\alpha$ (Fig. 8c) was observed at the beginning of the culture $(P<0 \cdot 05)$ but was not maintained. The oLH $\beta$ (data not shown) and oLH (Fig. 8d) have no effect on PRL release compared with the control.

\section{Discussion}

Our results demonstrate that differences in the stimulatory effect on PRL release of free $\alpha$ isoforms are related to biochemical features. Moreover, these features do not prevent the recombination of the free $\alpha$ isoforms with oLH $\beta$. However, the reconstituted dimers have differential LH activity depending on the free $\alpha$ considered.

Two free $\alpha$ isoforms were isolated from ovine pituitaries on the basis of their hydrophobic properties, suggesting that the ovine free $\alpha$ molecule exhibits polymorphism as previously described for the $\alpha$-subunit of glycoprotein hormones (Pierce \& Parsons 1981). Although large amounts of free $\alpha$ molecules were obtained, no free $\beta$-subunit was found, in agreement with studies in other species, indicating that the $\alpha$-subunit is synthesised in large excess over the $\beta$-subunit (Prentice \& Ryan 1975, Kourides et al. 1980b, Hoshina \& Boime 1982). This excess therefore favours the non-covalent association with $\beta$-subunit. Hence, the amount of $\alpha$-subunit does not limit the assembly with the $\beta$-subunit. However, an additional physiological role of this pituitary free $\alpha$ may be hypothesised. Indeed, one recent study suggests that free $\alpha$ from human pituitary might play a role during the menstrual cycle in women since $\alpha$-subunit from dissociated hCG acts synergistically with progesterone to induce decidualisation of endometrial cells (Moy et al. 1996). Moreover, dissociated TSH $\alpha$-subunit stimulates PRL release from myometrium of post-menopausal women (Stewart et al. 1995) and $\alpha$-subunit from dissociated FSH increases PRL levels released from bullfrog pituitary cells in culture (Oguchi et al. 1996).

Our study demonstrates that one of the two purified ovine free $\alpha$ isoforms (free $\alpha \mathrm{A}$ ) has a biological function of its own in stimulating PRL release from ovine foetal pituitary explants. This result reinforces the view that free $\alpha$ might play a paracrine role in the lactotroph function during pituitary development as previously suggested with heterologous $\alpha$-subunits from dissociated LH in rat pituitary explants (Bégeot et al. 1984) or reaggregate cells (Van Bael \& Denef 1996). In addition, our results reveal that the three $\alpha$ molecules (oLH $\alpha$ and the two free $\alpha$ isoforms) exhibit largely different potencies in stimulating PRL release from foetal pituitary explants. Indeed, free $\alpha \mathrm{B}$ appears to be devoid of activity, oLH $\alpha$ shows a transient effect, whereas the free $\alpha \mathrm{A}$ isoform exhibits significant activity over the 8 days of stimulation. In cultures of placental decidual cells, the only previous study which 
a)

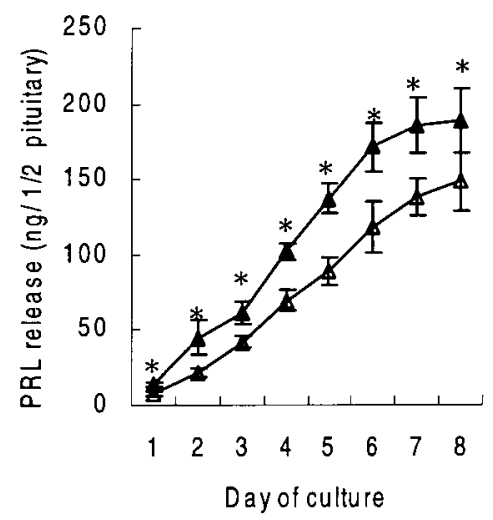

c)

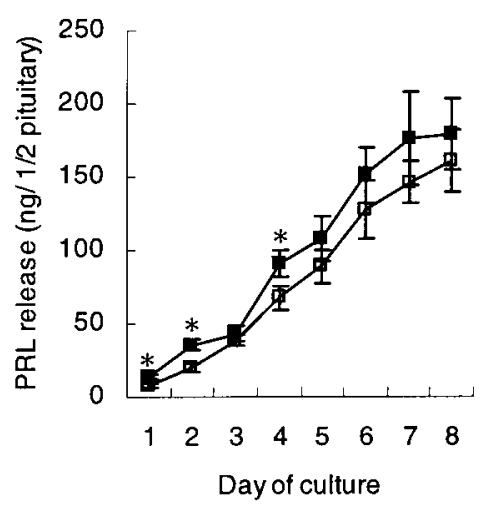

b)

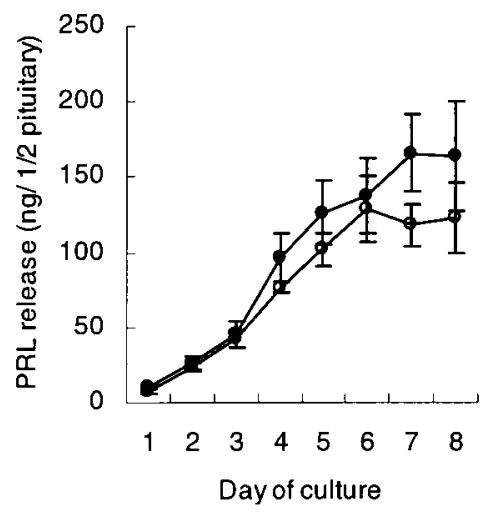

d)

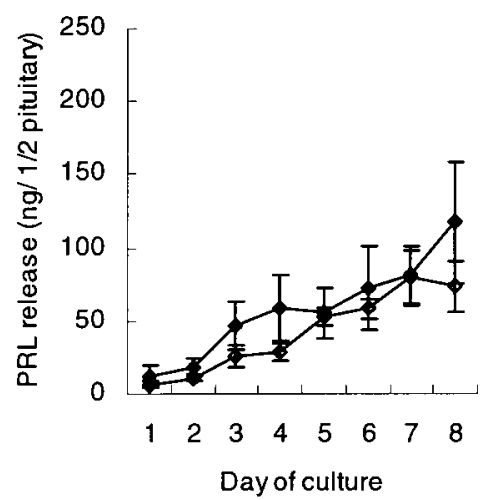

Figure 8 Effects of continuous treatments with free $\alpha \mathrm{A}$, free $\alpha \mathrm{B}$, oLH $\alpha$ or oLH on PRL release from ovine foetal pituitary explants in culture. Female pituitaries were collected at 50 days of gestation and cultured for 8 days without (open symbols) or with (closed symbols) free $\alpha \mathrm{A}$ (a), free $\alpha \mathrm{B}$ (b), oLH $\alpha$ (c) or oLH (d) at $10^{-7} \mathrm{M}$. Culture media were changed everyday and assayed for PRL by a competitive enzymatic immunoassay. Values are means \pm S.E.M. of three to five experiments. The effect of the treatments during the 8 days of the culture was estimated by ANOVA with repeated measures. ${ }^{*} P<0 \cdot 05$ (compared with the control at each day, by two-factor ANOVA).

compared the effects of hCG $\alpha$-subunit and placental free $\alpha$ showed that both of them display the same efficiency in stimulating PRL release (Blithe et al. 1991). Similar to human placenta, treatment of foetal pituitary explants with oLH $\beta$ or oLH has no or little effect on PRL release (Blithe et al. 1991). These results suggest that the stimulation of PRL release is specific for the $\alpha$ molecule in a free state, since oLH displays no activity. Furthermore, comparison of the activity of the three $\alpha$ molecules as part of reconstituted $\alpha / \beta$ heterodimers clearly shows that ovine free $\alpha$ molecules are capable of recombination with $\beta$-subunit in contrast to bovine and equine pituitary free $\alpha$ (Parsons et al. 1983, Bousfield \& Ward 1992). However, the dimers have different potencies. Indeed, the reconstituted free $\alpha \mathrm{B} / \mathrm{oLH} \beta$ dimer was as potent as the oLH $\alpha /$ oLH $\beta$ dimer and displayed a 4-fold higher efficiency than the reconstituted free $\alpha \mathrm{A} / \mathrm{oLH} \beta$ dimer in binding to the $\mathrm{LH}$ receptor and in stimulating testosterone secretion.

Taken together, these results reveal that the free $\alpha$ isoform, which is the most efficient on PRL release, is the least efficient at conferring LH activity on the $\alpha / \beta$ dimer. The fact that only one of the two free $\alpha$ molecules had an effect on PRL release strongly suggests the existence of some specific post-translational processing leading to $\alpha$ molecules with different activities either in the free state (PRL release stimulation) or in $\alpha / \beta$ heterodimeric state (gonadotrophic/thyrotrophic activity).

Characterisation by ES/MS, SE-HPLC and SDSPAGE clearly shows that ovine pituitary free $\alpha$ molecules 
are not of higher molecular mass than the oLH $\alpha$, in contrast to other species (Parsons et al. 1983, Bousfield \& Ward 1992). The free $\alpha \mathrm{B}$ isoform is even of smaller molecular mass than both the oLH $\alpha$ and the free $\alpha \mathrm{A}$ probably because of its truncated $\mathrm{N}$-terminus. Indeed, the lack of an average of three $\mathrm{N}$-terminal amino acid is in keeping with the difference of 400-500 mass units between the major component of the free $\alpha \mathrm{B}$ (13 $514 \mathrm{Da}$ ) and both the free $\alpha \mathrm{A}$ isoform (14019 Da) and oLH $\alpha$ (13 $937 \mathrm{Da})$. This was not specific for the ovine free $\alpha$, since similar heterogeneities in the N-terminal sequences of the LH or FSH $\alpha$-subunits of ovine, porcine and equine species have also been previously reported (Bousfield \& Ward 1984, Nomura et al. 1988, 1989) and attributed to proteolytic degradation.

After the removal of the two N-linked oligosaccharides by PNGase F treatment, SDS-PAGE analysis revealed that free $\alpha \mathrm{A}$ still exhibited a diffuse band despite its identical $\mathrm{N}$-terminus with oLH $\alpha$. Moreover, O-glycanase treatment did not reveal any O-linked oligosaccharides. This result is consistent with the observation that both free $\alpha \mathrm{A}$ and $\alpha \mathrm{B}$ fully recombine with oLH $\beta$ since the presence of an $\mathrm{O}$-linked carbohydrate in bovine free $\alpha$ has been shown to inhibit recombination with a $\beta$-subunit (Parsons \& Pierce 1984). Furthermore, small amounts of sialic acids were detected in free $\alpha \mathrm{A}$ and $\alpha \mathrm{B}$ in contrast to pituitary (Parsons et al. 1983, Bousfield \& Ward 1992) and secreted free $\alpha$ in other species (Kourides et al. 1980a, Blithe 1990a). Sialic acids therefore were not involved in charge heterogeneity of the two ovine free $\alpha$ isoforms. Taken together, these results demonstrate that $\mathrm{N}$-terminal amino acid sequence and oligosaccharide chains are not responsible for the more acidic charge and more hydrophobic feature of the free $\alpha \mathrm{A}$ isoform.

In spite of equal combination with oLH $\beta$, the two free $\alpha$ isoforms confer very different potencies to the $\alpha \beta$ dimers in the stimulation of testosterone secretion in rat Leydig cells. For the time being, the structural differences leading to inverse potencies of free $\alpha \mathrm{A}$ and $\alpha \mathrm{B}$ as PRL-releasing factors in the free state or as $\mathrm{LH}$ subunit remain elusive.

In conclusion, we have isolated two free forms of the glycoprotein $\alpha$-subunit in the ovine species which display divergent activities related to their charge and hydrophobicity. These results suggest that some, still unknown, post-translational modification(s) must control the fate of the $\alpha$ molecules either as potential subunits for glycoprotein hormones or as free molecules with intrinsic paracrine activity. The elucidation of the precise structural features of the $\alpha$ molecule either in dimers or in the free state, leading respectively to lower potency in the stimulation of testosterone secretion and in higher stimulation of PRL release, should provide important clues concerning the role of post-translational modification(s) on the structurefunction relationships in this molecule. In this respect, the search for a receptor of free $\alpha$ responsible for its action in lactotrophs would be of utmost interest.

\section{Acknowledgements}

The authors wish to thank A Locatelli for surgical assistance, Prof. A Verbert (Université des Sciences et Techniques de Lille I, Lille, France) and F Lecompte (INRA, Nouzilly, France) for performing ES/MS and carbohydrate analyses, C Gauthier and D André for providing ${ }^{125}$ I-labelled oLH, Dr D Guillaume for statistical advice, the US National Institutes of Health (NIH) for providing oTSH and oGH preparations (NIADDK-oTSH-12, oGH NIDDK-oGH-I-4) and Dr F Guillou for critical reading of the manuscript. This study was supported by a Grant from the French Ministry of Research and Education and partly by a financial contribution from Intervet (Angers, France) with the help of Critt Hyginov (Nouzilly, France).

\section{References}

Bégeot M, Hemming FJ, Dubois PM, Combarnous Y, Dubois MP \& Aubert ML 1984 Induction of pituitary lactotrope differentiation by luteinizing hormone $\alpha$ subunit. Science 226 566-568.

Blithe DL 1990a Carbohydrate composition of the $\alpha$-subunit of human choriogonadotropin (hCG $\alpha$ ) and the free $\alpha$ molecules produced in pregnancy: most free $\alpha$ and some combined hCG $\alpha$ molecules are fucosylated. Endocrinology 126 2788-2799.

Blithe DL $1990 b \mathrm{~N}$-linked oligosaccharides on free $\alpha$ interfere with its ability to combine with human chorionic gonadotropin- $\beta$ subunit. Journal of Biological Chemistry 265 21951-21956.

Blithe DL \& Iles RK 1995 The role of glycosylation in regulating the glycoprotein hormone free $\alpha$-subunit and free $\beta$-subunit combination in the extraembryonic coelomic fluid of early pregnancy. Endocrinology 136 903-910.

Blithe DL \& Nisula BC 1985 Variations in the oligosaccharides on free and combined $\alpha$-subunits of human choriogonadotropin in pregnancy. Endocrinology 117 2218-2228.

Blithe DL, Richards RG \& Skarulis MC 1991 Free alpha molecules from pregnancy stimulate secretion of prolactin from human decidual cells: a novel function for free alpha in pregnancy. Endocrinology 129 2257-2259.

Bloomfield GA, Faith MR \& Pierce JG 1978 Sepharose-linked concanavalin $\mathrm{A}$ in the purification and characterization of glycoprotein hormones of the bovine pituitary. Biochimica et Biophysica Acta 533 371-382.

Bos ES, Van der Doelen AA, Van Rooy N \& Schuurs AHWM 1981 3, $3^{\prime}, 5,5^{\prime}$-tetramethylbenzidine as an Ames test negative chromogen for horse-radish peroxidase in enzyme-immunoassay. Journal of Immunoassay 2 187-204.

Bousfield GR \& Ward DN 1984 Purification of lutropin and follitropin in high yield from horse pituitary glands. Journal of Biological Chemistry 259 1911-1921.

Bousfield GR \& Ward DN 1992 Reduction and reoxidation of equine gonadotropin $\alpha$-subunits. Endocrinology 131 2986-2998.

Cole LA, Perini F, Birken S \& Ruddon RW 1984 An oligosaccharide of the O-linked type distinguishes the free from the combined form of hCG $\alpha$-subunit. Biochemical and Biophysical Research Communications 122 1260-1267.

Combarnous Y 1992 Molecular basis of the specificity of binding of glycoprotein hormones to their receptors. Endocrine Reviews $\mathbf{1 3}$ 670-691.

Corless CL, Bielinska M, Ramabhadran TV, Daniels-McQueen S, Otani T, Reitz BA, Tiemeier DC \& Boime I 1987 Gonadotropin $\alpha$ subunit. Differential processing of free and combined forms in human trophoblast and transfected mouse cells. Journal of Biological Chemistry 262 14197-14203. 
Dubois MP 1971 Mise en évidence par immuno-fluorescence des cellules somatotropes et des cellules à prolactine dans l'hypophyse foetale des bovins. Compte Rendu de l'Académie des Sciences de Paris, Série D 272 433-435.

Guillou F, Martinat N \& Combarnous Y 1985 Rapid in vitro desensitization of the testosterone response in rat Leydig cells by sub-active concentrations of porcine luteinizing hormone. FEBS Letters 184 6-9.

Hagen C \& McNeilly AS 1975 Identification of human luteinizing hormone, follicle-stimulating hormone, luteinizing hormone $\beta$-subunit and gonadotrophin $\alpha$-subunit in foetal and adult pituitary glands. Journal of Endocrinology 67 49-57.

Hoshina H \& Boime I 1982 Combination of rat lutropin subunits occurs early in the secretory pathway. Proceedings of the National Academy of Sciences of the USA 79 7649-7653.

Iles RK, Wathen NC, Campbell DJ \& Chard T 1992 Human chorionic gonadotropin and subunit composition of maternal serum and coelomic and amniotic fluids in the first trimester of pregnancy. Journal of Endocrinology 135 563-569.

Kawano T, Endo T, Nishimura R, Mizuochi T, Mochizuki M, Kochibe N \& Kobata A 1988 Structural differences found in the sugar chains of eutopic and ectopic free $\alpha$-subunits of human glycoprotein hormone. Archives of Biochemistry and Biophysics 267 787-796.

Kourides IA, Hoffman BJ \& Landon MB 1980a Difference in glycosylation between secreted and pituitary free $\alpha$-subunit of the glycoprotein hormones. Journal of Clinical Endocrinology and Metabolism 51 1372-1377.

Kourides IA, Landon MB, Hoffman BJ \& Weintraub BD $1980 b$ Excess free alpha relative to beta subunits of the glycoprotein hormones in normal and abnormal human pituitary glands. Clinical Endocrinology 12 407-416.

Laemmli UK 1970 Cleavage of structural proteins during the assembly of the head of bacteriophage T4. Nature 227 680-685.

Liao T-H, Hennen G, Howard SM, Shome B \& Pierce JG 1969 Bovine thyrotropin: countercurrent distribution and a comparison with the isolated subunits of luteinizing hormone. Journal of Biological Chemistry 244 6458-6467.

Moy E, Kimzey LM, Nelson LM \& Blithe DL 1996 Glycoprotein hormone $\alpha$-subunit functions synergistically with progesterone to stimulate differentiation of cultured human endometrial stromal cells to decidualized cells: a novel role for free $\alpha$-subunit in reproduction. Endocrinology 137 1332-1339.

Nomura K, Tsunasawa S, Ohmura K, Sakiyama F \& Shizume K 1988 Renotropic activity in ovine luteinizing hormone isoform(s). Endocrinology 123 700-712.

Nomura K, Ohmura K, Nakamura Y, Horiba N, Shirakura Y, Sato Y, Ujihara M, Ohki K \& Shizume K 1989 Porcine luteinizing hormone isoform(s): relationship between their molecular structures, and renotropic versus gonadotropic activities. Endocrinology 124 712-719.
Oguchi A, Tanaka S, Yamamoto K \& Kikuyama S 1996 Release of $\alpha$-subunit of glycoprotein hormones from the bullfrog pituitary: possible effect of $\alpha$-subunit on prolactin cell function. General and Comparative Endocrinology 102 141-146.

Parsons TF \& Pierce JG 1984 Free $\alpha$-like material from bovine pituitaries. Removal of its O-linked oligosaccharide permits combination with lutropin- $\beta$. Journal of Biological Chemistry 259 $2662-2666$.

Parsons TF, Bloomfield GA \& Pierce JG 1983 Purification of an alternate form of the $\alpha$ subunit of the glycoprotein hormones from bovine pituitaries and identification of its $\mathrm{O}$-linked oligosaccharide Journal of Biological Chemistry 258 240-244.

Peters BP, Krzesicki F, Perini F \& Ruddon RW 1989 O-glycosylation of the $\alpha$-subunit does not limit the assembly of chorionic gonadotropin $\alpha \beta$ dimer in human malignant and non malignant trophoblast cells. Endocrinology 124 1602-1612.

Pierce JG \& Parsons TF 1981 Glycoprotein hormones: structure and function. Annual Review of Biochemistry 50 465-495.

Prentice LG \& Ryan RJ 1975 LH and its subunits in human pituitary, serum and urine Journal of Clinical Endocrinology and Metabolism $\mathbf{4 0}$ 303-312.

Saccuzzo-Beebe J, Krzesicki RF, Norton SE, Perini F, Peters BP \& Ruddon RW 1989 Identification and characterization of subpopulations of the free $\alpha$-subunit that vary in their ability to combine with chorionic gonadotropin- $\beta$. Endocrinology 124 1613-1624.

Sairam MR \& Li CH 1974 A simple procedure for separating the subunits of ovine and bovine pituitary interstitial cell stimulating hormone. Archives of Biochemistry and Biophysics 165 709-714.

Stewart EA, Jain P, Penglase MD, Friedman AJ \& Nowak RA 1995 The myometrium of postmenauposal women produces prolactin in response to human chorionic gonadotropin and $\alpha$-subunit in vitro. Fertility and Sterility 64 972-976.

Vaitukaitis JL 1974 Changing placental concentrations of human chorionic gonadotropin and its subunits during gestation. Journal of Clinical Endocrinology and Metabolism. 38 755-760.

Van Bael A \& Denef C 1996 Evidence for a trophic action of the glycoprotein hormone $\alpha$-subunit in rat pituitary. Journal of Neuroendocrinology 8 99-102.

Ward DN, Bousfield GR \& Mar AO 1989 Chemical reductionreoxidation of the glycoprotein hormone disulfide bonds. In Structure-Function Relationship of Gonadotropins, vol 65, pp 1-19. Eds D Bellet \& JM Bidart. New York: Raven Press.

Watanabe YG, Matsumura H \& Daikoku S 1973 Electron microscopic study of rat pituitary primordium in organ culture. Zeitschrift für Zellforschung und Mikroskopische Anatomie 146 453-461.

Received 19 July 1999

Accepted 27 October 1999 